\title{
Psalm 118 (117 lXx) in Luke-Acts: Application of A ‘New Exodus Motif'
}

Author:

Hyuk J. Kwon

\section{Affiliation:}

${ }^{1}$ Department of New

Testament, University of

Pretoria, South Africa

Correspondence to:

Hyuk Kwon

e-mail:

gert.steyn@up.ac.za

Postal address:

Department of New

Testament Studies, Faculty

of Theology, University of

Pretoria, Pretoria, Gauteng

0002, South Africa

\section{Keywords:}

Luke-Acts; New Exodus

Motif; Psalm 118; New

Testament hermeneutics;

Targum

Dates:

Received: 16 Feb. 2009

Accepted: 04 Apr. 2009

Published: 09 Dec. 2009

How to cite this article: Kwon, H.J., 2009, 'Psalm 118 (117 lxx) in Luke-Acts: Application of a "New Exodus Motif"', Verbum et Ecclesia 30(2), Art. \#59, 6 pages. DOI: $10.4102 /$ ve.v30i2.59

\section{This article is available} at:

http://www.ve.org.za
(C) 2009. The Authors. Licensee: OpenJournals Publishing. This work is licensed under the

Creative Commons

Attribution License.

\section{ABSTRACT}

This contribution explores the presence of Psalm 118 (117 LXX) in Luke-Acts. The Wirkungsgeschichte of Psalm 118 will be traced by means of a twofold approach: from a traditional-historical and a hermeneutical angle with regard to the reception history of Psalm 118. Firstly, in terms of a traditional-historical, otherwise known as a diachronic, approach, the background of Psalm 118 and evidence of the use and application of Psalm 118 in the tradition (namely in the ancient Jewish materials, such as the Dead Sea Scrolls, the Targums, and Rabbinics, and the New Testament books of Mark, Matthew, Luke, Acts, John, Romans, 2 Corinthians, Ephesians, 1 Peter, Hebrews, Revelation, as well as in terms of Church Fathers 1 Clement and Barnabas and the Apocryphon Thomas) will be discussed. Secondly, on the hermeneutical level, otherwise known as the synchronic approach, the function and interpretation of the quotations of Psalm 118 in its new context of Luke-Acts will be examined. In terms of the latter approach, attention will be paid to investigating a possible underlying 'New Exodus Motif'.

\section{INTRODUCTION}

There are numerous psalm quotations in the New Testament. ${ }^{1}$ Among such quotations, the use of Psalm 118 in the New Testament is conspicuous. According to the tables of quotation of the United Bible Societies (UBS 3rd edn.) and Nestle-Aland 27th edn., Psalm 118 is one of the most quoted psalms in the New Testament, and perhaps the most quoted Old Testament chapter. ${ }^{2}$ However, the same amount of attention has not been paid to the occurrence of Psalm 118 in the New Testament. Such a situation calls for closer investigation into the use and interpretation of Psalm 118 in the New Testament.

Psalm 118 belongs to the so-called 'Egyptian Hallel Psalms' (Ps 113-118). These psalms were praises sung as part of the liturgy during the major Jewish feasts of the Passover, the Pentecost and the Tabernacles. Psalm 118 was especially related to the feast of the Passover, which serves as a reminder of the Exodus from Egypt. During the festival, pilgrims recounted the deeds performed by Yahweh to save the Jewish people during their exodus from Egypt, under the leadership of Moses. The question is whether the early Christian writers, especially the New Testament authors, had the New Exodus Motif $^{3}$ in mind when they quoted from Psalm 118

\section{THE TRADITIONAL-HISTORICAL ASPECT OF PSALM 118}

\section{The background of Psalm 118}

As with many of the psalms, when and under what circumstances Psalm 118 was composed still remains a matter of scholarly controversy. The majority view today is that the psalm was composed in the post-exilic era as a liturgy intended as part of a festival of thanksgiving (Kraus 1989:395).

Psalm 118 forms part of the Hallel Psalms, ${ }_{,}^{4}$ which were specifically composed for festivals and pilgrimages (West 1981:440). Hallel Psalms 113-118, as a unit, are called the so-called 'Egyptian Hallel', since they recount the saving deeds of Yahweh performed during the Exodus from Egypt under the leadership of Moses (to whom the authorship of the psalms was traditionally attributed) (Swanson 1992:30). Hence, they were customarily related to the Passover (Schaefer 2001:288). The Hallel was first sung at the Feast of the Lights (also known as the Hanukkah), as is made clear by the inclusion of Psalm 118:27, which states 'Yahweh is God, he is our light'. The liturgical use of Psalm 118 was later extended to the three great festivals of the Passover, the Pentecost and the Tabernacles (De Vaux 1980:512). Psalm 118 is a bridging psalm, as it not only forms the conclusion of the Egyptian Hallel group of psalms, but also belongs to the opening of the Great Hallel, consisting of Psalms 118-136.

\section{Psalm 118 and its motifs}

Psalm 118, as the climax of the Egyptian Hallel, includes a number of Exodus parallels and connections which make it very suitable for use during Passover. Firstly, many similarities exist in the vocabulary of Exodus 14 and Psalm 118. Mays (1988:304) notes the stark verbal contrast between 'die' in Ex 14:1112 and 'not die' in Psalm 118:17-18. Prinsloo (2003:415) also mentions the verbal similarities existing

1.The UBS ${ }^{3}$ lists 79 different verses taken from 40 psalms as being cited in the New Testament. New Testament citations from the Old Testament come mainly from the Pentateuch (51), the Psalter (40) and Isaiah (38) (Ellis 2000:52; Swete 1900:386).

2.According to UBS, ${ }^{3}$ with Exodus 20, Psalm 118 is the most frequently quoted Old Testament chapter in the New Testament. According to $\mathrm{NA}^{27}$, Psalm 118 is found 24 times in the New Testament (11 quotations and 13 allusions).

3.It is necessary to distinguish between 'the Exodus Motif' and 'the New Exodus Motif'. The former is based on 'the Exodus from the Egyptian Exile.' The latter finds its model in the Exodus from the Babylonian Exile. In the process of salvation history, there is also development in the Exodus Motif. The prophets transformed the first Exodus into a New Exodus. As God delivered the Israelites from Egypt in the past, he will save them in the future from from Exp in eschatological concept of a New Exodus in the book of Isaiah, especially in Isaiah 40-66.

4. The name 'Hallel Psalms' has been variously used to describe the following psalm groups: 104-106, 111-118, 120-136, and 146-150 (Swanson 1992:30) 
between Exodus 14:30-31 and Psalm 118 as follows: 'saved' (Ex 14:30a) and 'save' (Ps 118:14b, 15a, 21b, 25a); 'that day' (Ex 14:30b) and 'this day' (Ps 118:24a); 'saw' (Ex 14:30-31a) and 'look down upon' (Ps 118:7b); 'Yahweh did' (Ex 14:31b) and 'the deeds of Yahweh' (Ps 118:17b); and '[t]he people feared Yahweh' (Ex 14:31c) and 'those who fear Yahweh' (Ps 118:4a).

Secondly, several scholars see intertextual links between Psalm 118 and the so-called Song of Moses (Ex 15:1-21). Dahood (1970:156) has, for instance, emphasised the verbal similarities between Psalm 118 and the ancient victory hymn in Exodus 15:14 with Exodus 15:2,5 Exodus 15:15-16 with Exodus 15:6; and Exodus 15:28 with Exodus 15:2. Prinsloo (2003:415) also notes the strong verbal connection: Exodus 15:2ab is cited verbally in Psalm 118:14ab. Furthermore, Exodus 15:2b is alluded to in Psalm 118:21b, with Exodus 15:2bc being alluded to in Psalm 118:28bc.

The intertextual relationships existing between Psalm 118 and the New Exodus passages reflect the eschatological expectation of the restoration of Israel. Isaiah $26^{6}$ and Zechariah 10, both of which were composed in the context of Judah's eschatological restoration, include striking parallels with Psalm 118 (Prinsloo 2003:416-417): 'that day...salvation' (Is 26:1) versus 'this day' (Ps 118:24a), 'save' (Ps 118:14b, 15a, 21b); 'open the gates that the righteous nation...enter' (Is 26:2) versus 'open for me the gates of righteousness' (Ps 118:19a), 'enter' (Ps 118:19b), 'the gate of Yahweh' (Ps 118:20a), 'the righteous may enter through it' (Ps 118:20b); and 'cornerstone' (Zch 10:4) versus 'cornerstone' (Psalm 118:22).

\section{Psalm 118 in the Jewish and early Christian traditions}

Psalm 118 (LXX 117) itself was closely associated with the Passover by the Jews, as well as with the celebration of Easter by the early Church (Thomas 1965:319). According to Kistemaker (1961:57), Psalm 118 was 'sung during the entire week following Easter Sunday, being the last remnant of the seven-day long Jewish celebration of Passover'. Werner (1959:57) argues similarly, saying that 'apparently this psalm citation belonged to the liturgy of synagogue and church'.

\section{The use of Psalm 118 in the Jewish tradition Psalm 118 in the Dead Sea Scrolls \\ Although numerous copies of various psalms were found in the Qumran library, few manuscripts were found to preserve portions of Psalm 118.7 Among the few such that remain extant, the scroll 11QPs ${ }^{a}$, which includes six verses from Psalm 118 in column XVI has aroused great interest, due to its unusual arrangement and contents. ${ }^{8}$ The sequence has been found to consist of Psalms 135, 136, as well as parts of Psalms 118 and 145 , accompanied by some additional inserts and a (largely missing) subscription (Skehan 1973:195).}

Whether $11 \mathrm{QPs}^{\mathrm{a}}$ is a scriptural Psalter or a secondary collection, all parties have suggested the strong Davidic emphasis in the scroll, which recognises the importance of David's compositions, with the prose 'epilogue' 9 that appears in column XXVII (Flint 1997:176-177). According to Wacholder (1988:23), the strong

\footnotetext{
5.Psalm 118:14 is the classic statement, coined by the song sung after the victory at the Red Sea in Moses' days (Ex 15:2) and then again used effectively in Isaiah's days (Is 12:2), The Lord is my strength and my salvation. The echoes of the hymn days (Is 12:2), The Lord is my strength and my salvation. The
ring down to the New Testament (Rv 15:3) (Leupold 1972:815).

6.Psalm 118 parallels Exodus 15:2, and Isaiah 26:2, 11 (Botha 2003:211)

7.Segments of Psalm 118 are found in the following scrolls: Psalms 118:25-29 (11QPs fragment E I); 118:1, 15, 16, 8, 9, 20 (11QPs $\left.{ }^{\mathrm{a}} \mathrm{col} X \mathrm{XVI}\right) ; 118: 1,5,16\left(11 \mathrm{QPs}^{\mathrm{b}}\right)$ $118: 1-3,6-12,18-20,23-26,29\left(4 \mathrm{QPs}^{\mathrm{b}}\right) ; 118: 29\left(4 \mathrm{QPs}^{\mathrm{e}}\right)$.

8.According to Abegg, Flint and Ulrich (1999:505), from Psalm 91 onward, many of the psalms scrolls differ radically from the MT Psalter. The variations involved are of two chief types: variations in arrangement (referring to the different order of the psams) chief types: variations in arrangement (referring to the different order of the psalms)
and variations in content (referring to the inclusion of compositions not found in the and variations in content (re
}

9.That is to say, the last columns of the scroll end with an emphasis on David.
Davidic emphasis of the Dead Sea Scrolls may suggest an eschatological reading of Psalm 118. Brunson (2003:88) supports Wacholder's view, arguing that the combination of psalms in Fragment E would have promoted eschatological aspirations, since Psalms 118, 104 and 105 contain references to the Exodus, and Psalm 147 mentions the future gathering of the Exiles.

Another compelling explanation for the unusual arrangement of $11 \mathrm{QPs}^{\mathrm{a}}$ is that it is arranged according to liturgical considerations. Whether or not the compiler borrowed phrases from Psalm 118 to shape a new psalm, it seems that the Catena was an intentional grouping, liturgical in purpose ${ }^{10}$ and so the fact that the psalm provides material for the liturgical complex implies that it was well-known and adaptable, and that it played an important liturgical role. The occurrence of Psalm 118:25-29 in Fragment E might suggest the use of the Hallel as a unit, or, alternatively, might have served to shape the part of another liturgical complex. Therefore, it is probable that the Dead Sea Scrolls largely provide examples of the liturgical use of Psalm 118 , rather than a simple copying of the psalm in its biblical order (Brunson 2003:86-87).

\section{Psalm 118 in the Targum}

Compared with Masoretic Text Psalm 118:22, the Aramaic tradition interprets 'stone' as 'a youth'. Most scholars (Evans 2001:238; Jeremias 1966:259; Strack \& Billerbeck 1965:876) understand the reference to the youth to be a reference to David. The fact that the young man was identified as being one of the sons of Jesse, and that all those concerned in the antiphonal praise were contemporaries of David support the idea that the reference was to David himself (Snodgrass 1973:83). Accordingly, the Targum on Psalm 118 seems to incorporate themes from David's life, beginning with his initial rejection in his youth, continuing through his acceptance as Israel's king, and ending with Samuel's offering of a sacrifice to celebrate young David's accession to the throne (Evans 2001:229).

Gärtner (1953:100-101), however, interprets the reference to the youth to be a reference to the Messiah himself, meaning David's son, suggesting that 'king' and 'rule' are terms used in connection with the Messiah. The Messianic-eschatological interpretation of other Old Testament stone passages and the description of the stone as a ruler/king increases the possibility that similar associations could be made with Psalm 118:22 (Brunson 2003:41).

\section{Psalm 118 in the Rabbinic literature}

As Table $1^{11}$ demonstrates, the Hallel, as a whole, was interpreted eschatologically and/or Messianically in late Judaism.

The second section of the Hallel in particular was interpreted Messianically in rabbinic literature. Such an eschatological interpretation is well represented in the Midrash on the Psalms, especially in 118, §22, which is presented in Table 2.

For instance, the Midrash on Psalms 118, \$22 interprets Psalm 118:24 as referring to the day of deliverance which ends all slavery eternally, namely to the Messianic redemption (Brunson 2003:92-93).

\section{The use of Psalm 118 in the early Christian tradition}

- Possible Psalm 118 (117 LXX) references in the early Christian tradition consist of the following:

- Psalm 118:5, 21 (117 LXX) are alluded to in John 11:41-42.

- Psalm 118:6 (117 LXX) is quoted (Hab 13:6), and alluded to once (Rm 8:31b), in the New Testament.

- Psalm 118:10-12 (117 LXX) are alluded to in John 10:24-25.

- Psalm 118:15 (117 LXX) is alluded to in Luke 1:51.

10.Skehan (1973:195) contends that the Catena forms the clearest of the liturgical groupings in the scroll. Some scholars are of similar opinion (Goshen-Gottstein 1966:24; Talmon 1966:12; Wacholder 1988:43-44, 48).

11.Jeremias (1966:256-257). 
TABLE 1

Interpretation of the Hallel

\begin{tabular}{|c|c|}
\hline Hallel & Rabbinic Literature \\
\hline Psalm 113:2 & The praise of God in the world to come (Midr Ps 113:4) \\
\hline Psalm 113:9 & Zion in the end time (Pes 141a) \\
\hline Psalm 115:1 & $\begin{array}{l}\text { The suffering of the Messianic times and the war against } \\
\text { Gog and Magog (b Pes 118a) }\end{array}$ \\
\hline Psalm 116:4 & $\begin{array}{l}\text { Saving of the souls of the pious from Gehenna (b Pes } \\
\text { 118a) }\end{array}$ \\
\hline Psalm 116:9 & $\begin{array}{l}\text { Resurrection of the dead (b Pes 118a); the eschatological } \\
\text { meal (Ex R } 25.10 \text { on 16:4) }\end{array}$ \\
\hline Psalm 116:13 & $\begin{array}{l}\text { David's table-blessing after the meal of the salvation time } \\
\text { (b Pes } 119 \text { b; Ex R } 25.10 \text { on 16.4) }\end{array}$ \\
\hline Psalm 118:7 & The last judgement (Midr Ps 118, §10) \\
\hline Psalm 118:10-12 & War against Gog and Magog (Midr Ps 118, §12) \\
\hline Psalm 118:15 & Beginning of the Messianic times (Pes 132a) \\
\hline Psalm 118:24 & The Messianic redemption (Midr Ps 118, §22) \\
\hline Psalm 118:24-29 & The antiphonal choir at the Parousia (Midr Ps $118, \S 22$ ) \\
\hline Psalm 118:27a & God, the light of salvation, time (Midr Ps $36, \S 6$ ) \\
\hline Psalm 118:27b & The days of Gog and Magog (j Ber 2.4d.49) \\
\hline Psalm 118:28 & The future world (j Ber 2.4d.50) \\
\hline
\end{tabular}

TABLE 2

The Midrash on Psalm 118, $\$ 22^{12}$

$\begin{array}{ll}\text { Psalm 118:24 } & \begin{array}{l}\text { After all the redemptions that came to Israel, enslavement } \\ \text { followed, but from this point on no enslavement would follow }\end{array}\end{array}$
followed, but from this point on no enslavement would follow, as is stated.

Psalm 118:25 From inside the walls, the men of Jerusalem will say, 'We beseech Thee, O Lord, save now!' And, from outside, the men of Judah will say, 'We beseech Thee, O Lord, make us now to prosper!'

Psalm 118:26 From inside, the men of Jerusalem will say, 'Blessed be he that cometh IN the name of the Lord!' And, from outside, the men of Judah will say, 'We bless you OUT of the house of the Lord!'

Psalm 118:27 From inside, the men of Jerusalem will say, 'The Lord is God and hath given us light'. And, from outside, the men of Judah will say, 'Order the festival procession with boughs, even unto the horns of the altar!'

Psalm 118:28 From inside, the men of Jerusalem will say, 'Thou art my God and I will give thanks unto Thee'. And, from outside, the men of Judah will say, 'Thou art my God, I will exalt Thee'.

Psalm 118:29 Then the men of Jerusalem and the men of Judah, together opening their mouths in praise of the Holy One, blessed be $\mathrm{He}$, will say ' $\mathrm{O}$ give thanks unto the Lord, for $\mathrm{He}$ is good, for $\mathrm{He}$, will say 'O give thanks un
$\mathrm{His}$ mercy endureth for ever'.

- Psalm 118:16 (117 LXX) is alluded to in Luke-Acts three times: Luke 1:51; Acts 2:33; Acts 5:31.

- Psalm 118:17-18 (117 LXX) are alluded to in 2 Corinthians 6:9.

- Psalm 118:20 (117 LXX) is alluded to in Revelations 22:14

- Psalm 118:22-23 (117 LXX) is one of the favourite parts of Psalm 118 among the early Christian writers. The verses are found at least ten times in the early Christian literature (Mk 8:31; Mk 12:10-11; Mt 21:42; Lk 9:22; Lk 17:25; Lk 20:17; Ac 4:11; Rm 9:32-33; Eph 2:20; 1 Pt 2:7; Gl 66; Barn 6:2-4).

- Psalm 118:24 (117 LXX) is alluded to in John 8:56 and in Revelations 19:7.

- Psalm 118:25-26 (117 LXX) are quoted at least six times in the Gospels (Mk 11:9-10; Mt 21:9; Mt 23:39; Lk 13:35, Lk 19:38; Jn 12:13) and are alluded to twice in the Synoptics (Mt 11:3; Lk 7:19).

12.This translation of the Midrash on the Psalms 118 , $§ 22$ was borrowed from Braude (1959:245)
Psalm 118 in the Synoptics

The Synoptic writers concentrate on Psalm 118:22-23, 25-26 (117 LXX). Although the citation from Psalm 118:22-23 in the Synoptics follows the LXX text of Psalm 117 closely, the writers apply it to a different context and reinterpret it Christologically. 'The builders', who referred to 'the nations' in the LXX Ps 117:22 now turn out to be 'the leaders of Israel'. In the original psalm, 'the stone which the builders rejected' referred to 'the nation of Israel' or 'Israel's king'. In the Synoptics, the term is applied to Jesus.

Unlike Psalm 118 (117 LXX):22-23, the lines from Psalm 118 (117 LXX):25-26 about the blessedness of the one who comes in the name of the Lord are expressed in various ways in the Synoptics. Matthew, after speaking of the crowds giving praise to 'the son of David', cites the psalm, and then notes the cries of 'Hosanna in the highest'. Mark speaks of those going before and behind crying hosanna, cites the psalm, notes another blessing for 'the coming kingdom of our Father David', and closes with cries of 'Hosanna in the highest'. Luke does not mention the crying out of 'Hosanna!', but speaks of 'the king' and 'peace in heaven, and glory in the highest heaven'. Like Psalm 118 (117 LXX):22-23, Psalm 118 (117 LXX):25-26 is Christologically interpreted by the Synoptics. The phrase 'Blessed is the one who comes in the name of the LORD', which originally referred to the benediction pronounced upon 'those coming or entering the gates of the temple' was changed into 'the welcome for Jesus as the coming Messiah' (Menken 2004:70).

\section{Psalm 118 in the Gospel of John}

While the Synoptics focus on a few verses of Psalm 118 (117 LXX) (22-23, 25-26), the Fourth Gospel employs a wider range of wording from Psalm 118 (117 LXX) (5, 10-12, 19-20, 21, 24, 2526), but does not use the wording of Psalm 118 (117 LXX):22. John 12:13 contains the only quotation from Psalm 118 (117 LXX). Like the Synoptic parallels, the Psalm 118 (117 LXX) quotation in John has no introductory formula, and is also suitably contextualised by adding the note of blessing on 'the king of Israel'. In the title, which forms an inclusio with Nathanael's confession at the introduction of the Gospel, the phrase 'the coming one' and the quotation from Zechariah 9:9 in John 12:15, John describes Jesus as a Messianic king who comes to bring the New Exodus to his people (Daly-Denton 2004:127).

\section{Psalm 118 in the Pauline Epistles}

The Pauline literature does not quote Psalm 118 (117 LXX) directly, but merely alludes to the stone text of Psalm 118:22 at least twice ( $\mathrm{Rm}$ 9:32-32 and Eph 2:20), and applies 'the stone' to 'Christ'. It seems, therefore, that there is an underlying possibility of the New Exodus Motif in Paul's allusions to Psalm 118 (117 LXX) (Dunn 1988:594).

\section{Psalm 118 in the General Epistles}

In Hebrews 13:6, Psalm 118 (117 LXX) is quoted in relation to the Jewish feasts, namely to the Sabbatical Year, the Tabernacles and the Passover, all of which are closely associated with Exodus themes (Steyn 2006:130). By using the Psalm 118:22 citation, sandwiching it between two Isaianic quotations, 1 Peter seems to depict Jesus as Isaiah's righteous servant, whose task it was to bring the New Exodus to his church through his suffering and death (Nixon 1963:28).

\section{THE HERMENEUTICAL ASPECT OF PSALM 118 IN LUKE-ACTS}

According to Doble (2004:83), Luke stressed that Jesus' story was the fulfilment of the Old Testament, especially in terms of the psalms. Fourteen psalm quotations are given in Luke-Acts, four of which come from Psalm 118 (117 LXX). The quotations appear in Luke 13:35 (Ps 118[117 LXX]:6); Luke 19:38 (Ps 118[117 LXX]:26); Luke 20:17 (Ps 118[117 LXX]:22); and Acts 4:11 (Ps 118[117 LXX]:22). 


\section{The New Exodus Motif in Luke-Acts}

Luke describes the journey of Jesus as his 'Exodus', which will be fulfilled in Jerusalem (Lk 9:31). In so doing, Luke clearly thinks particularly of the eschatological New Exodus, which is depicted in Isaiah 40-66. ${ }^{13}$ Such an approach not only matches Luke's eschatological viewpoint and massive interest in the book of Isaiah well, ${ }^{14}$ but it also corresponds with his unique Christology, which focuses on 'Jesus' role as the expected Davidic Messiah, Isaianic servant and prophet like Moses'. Luke understands Jesus to be a Davidic king, who (like Moses) brings an eschatological New Exodus to his people through his suffering as the Lord's servant. The New Exodus Motif is continued in Acts, where Jesus' apostles follow the New Exodus way of deliverance, which is manifested throughout his entire life (Strauss 1995:304).

The interpretation of Psalm 118 in the Gospel of Luke Three explicit quotations from Psalm 118 (117 LXX) appear in Luke's Gospel, with the New Exodus Motif being given in each citation. ${ }^{15}$ Whereas the first citation appears in a different place in Matthew's Gospel, the second and last are distinctively Lukan. The third quotation is shared with Mark and Matthew (Wagner 1997:156-157).

\section{The lament over Jerusalem (Lk 13:31-35)}

A comparison of the reading of the Greek texts of Psalm 117:2526 (LXX) with Luke 13:35 appears in Table 3.

TABLE 3

Comparison of the reading of the Greek texts of Psalm 117:25-26 (LXX) with Luke 13:35

\begin{tabular}{|c|c|}
\hline LXX & Lk 13:35 \\
\hline 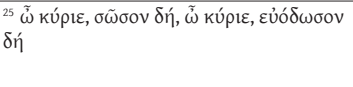 & 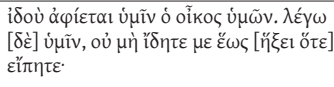 \\
\hline 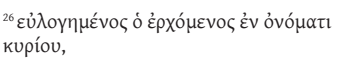 & 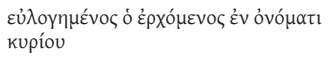 \\
\hline 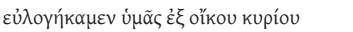 & \\
\hline
\end{tabular}

While Luke 13:34-35 shares the same citation and much of its situation with Matthew 23:37-39, Luke drastically recontextualises it (Doble 2004:85-86). Matthew positions the lament after Jesus has arrived in Jerusalem between the Woes (23:1-36) and the Apocalyptic Discourse (24:1-25:46). In such a context, Psalm 118 (117 LXX):26 clearly refers to the end of days. Luke, however, incorporates the episode into his long journey narrative (Lk 9:51-19:27), before Jesus' entrance into Jerusalem. Therefore, the wording of Psalm 118 (117 LXX):26 most naturally refers to Jesus' expected arrival in Jerusalem (Wagner 1997:163). In Luke 13:34, Jesus complains that he often wanted to gather in, love, and protect his people, but they were not willing to accept him in this way. Consequently, judgement on the temple is proclaimed: 'Your house is left to you desolate' (Lk 13:35a). A quote from Psalm 118 (117 LXX) follows: 'You will not see me until you say, "Blessed is the one who comes in the name of the Lord" (Lk 13:35b)'. They will not see him again before the day when he is welcomed into Jerusalem as the end-time Messiah. The words of hail are taken from Psalm 118 (117 LXX):26, and are employed by the multitudes of disciples in an anticipatory way in 19:38 (Nolland 1993a:742).

Psalm 118 (117 LXX):26 refers to the priests' benediction of those who came to worship in the temple, who were perhaps pilgrims

13.Numerous recent studies review the Lukan writings in light of the Isaianic New Exodus programme (cf. Denova 1997; Pao 2000; Sanders 1982; Seccombe 1981; Strauss 1995; Turner 1996).

14.According to Koet (2005:79-80), there are nine explicit Isaiah quotations (of which four are in Luke and five are in Acts) in the Lukan writings, namely Isaiah 40:3-5 (Lk 3:4-6); Isaiah 61:1-2a (Lk 4:18-19); Isaiah 56:7 (Lk 19:46); Isaiah 53:12 (Lk 22:37); Isaiah 66:1-2a (Ac 7:49-50); Isaiah 53:7-8c (Ac 8:32-33); Isaiah 55:3 (Ac 13:34); Isaiah 49:6 (Ac 13:47) and Isaiah 6:9-11a (Ac 28:26-27).

15.Psalm 118 (117 LXX):25-26 in Luke 13:5, Psalm 118 (117 LXX):26 in Luke 19:38, and Psalm 118 (117 LXX):22 in Luke 20:17. led in procession by the king (Bock 1996:1250). Luke reinterprets the benediction Christologically: 'a Messianic exclamation and greeting, here referring to the (eschatological) moment when Israel will acknowledge Jesus as its Messiah' (Reiling \& Swellengrebel 1971:520). The key phrase 'the coming one' amounts to Messianic terminology in Luke's Gospel: in Luke 3:15-16 and Lk 7:19 the expression alludes to the coming Messianic figure, who brings God's salvation. In both the pericope and Lk 19:38, the phrase also has clear Messianic overtones (Bock 1996:1250).

The triumphal entrance (Lk 19:28-40)

A comparison of the reading of the Greek texts of Psalm 117:26 (LXX) with Luke 19:38 appears in Table 4.

TABLE 4

A comparison of the reading of the Greek texts of Psalm 177:2 (LXX) with Luke 19:38

\begin{tabular}{|c|c|}
\hline LXX & Lk 19:38 \\
\hline & $\lambda \varepsilon ́ \gamma$ \\
\hline 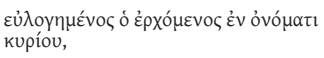 & 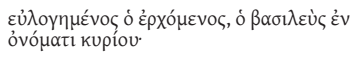 \\
\hline 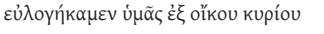 & \\
\hline
\end{tabular}

The second quotation of Psalm 118 (117 LXX) occurs in the context of Jesus' entry into Jerusalem (Lk 19:28-40). The goal of the Isaianic New Exodus is to reach Jerusalem/Zion (Is 35:10; 40:9; 51:11), where Yahweh's glory will be revealed (Is 40:5; 52:10), and where he will reign as king (Is 52:7). In Luke, too, the emphasis is on Jerusalem. Hahn pinpoints the priority of Jerusalem in Luke:

For Luke, it is theologically important that the word of God go forth from Jerusalem to the ends of the earth (Lk 24:47; Ac 1:8; cf. Is 2:3). The gospel begins in Jerusalem (1:5-23), the only two narratives from Jesus' childhood find him in Jerusalem (2:22-52), for most of the narrative he is travelling to Jerusalem (9:51-19:27), and the gospel climaxes in Jerusalem (19:28-24:49), wherein the disciples are told to 'remain' (24:49).

(Hahn 2005:303-304)

Luke inserts his interpretative comment 'o $\beta \alpha \sigma \iota \lambda \epsilon u \varsigma^{\prime}$ in Luke 19:38. By adding the word to the original psalm, Luke, like Matthew, relates the citation from Psalm 118 (117 LXX):26 to the prophecy in Zechariah 9:9 (Ellis 1966:227).

Though Luke has previously referred to Jesus' Davidic link (1:32; 18:38-39), here he directly calls Jesus 'king' (Bock 1996:1558). According to Doble (2004:86), 'from Annunciation (Lk 1:32-35) to Paul's dialogues (Ac 28:23-24), Luke's work is founded on Jesus' being the long-awaited Davidic king'. The reference to the king makes it plain that a royal figure is in view, which might be a further allusion to Zechariah 9:9 (Bock 1996:1558).

In contrast to Mark, Luke intentionally drops Mark's addition to Psalm 118 (117 LXX) of 'the coming kingdom of our father David'. According to Brunson (2003:117-118), Luke drops Mark's distinct expression, 'perhaps to avoid political misunderstanding and/or to counter the impression that the kingdom of God should have been inaugurated on or shortly after Jesus' arrival to Jerusalem'. By removing Mark's vague expression 'kingdom of our father David', Luke clearly identifies Jesus as king (Kinman 1995:117).

The parable of the wicked tenants (Lk 20:9-19)

A comparison of the reading of the Greek texts of Psalm 117:22 (LXX) with Luke 20:17 appears in Table 5.

TABLE 5

Comparison of the reading of the Greek texts of Psalm 177:22 (LXX) with Luke 20:17

\begin{tabular}{|c|c|}
\hline LXX & Lk 20:17 \\
\hline & 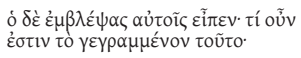 \\
\hline 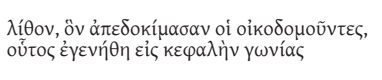 & 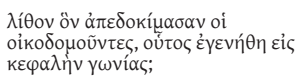 \\
\hline
\end{tabular}


Compared with Mark and Matthew, Luke's citation of the Old Testament does not include Psalm 118 (117 LXX):23 this was done by the Lord and it is an amazing thing in our eyes', as in Mark 12:11 and Matthew 21:42b. The reason for Luke's omission of the quotation from Psalm 118 (117 LXX):23 is explained by scholars in the following ways:

- the omission in Luke of Psalm 118 (117 LXX):23 is 'due to his proclivity to omit irrelevant parts rather than a theological motivation' (Snodgrass 1983:62);

- Luke, thereby, is able to concentrate exclusively on the rejection theme, just as he also does with the identical quotation in Acts 4:11 (Johnson 1991:306);

- such an omission might allow for a closer connection with Acts 4:18, which maintains the stone imagery (Nolland 1993b:952). Another possible reason for the omission lies in Luke's development of his narrative over two volumes, allowing for Psalm 117:23 (LXX) to be referred to in Paul's speech at Pisidian Antioch (Ac 13:41) (Doble 2004:86). All of the above explanations seem plausible.

Unlike the previous two quotations from Psalm 118 (117 LXX) (Lk 13:35; 19:38), Luke 20:17 introduces a new theme, that of the rejected (by the builders), yet exalted (by God), stone. In the psalm, use of the builders as a term refers to the nations. However, Luke applies the term to the builders of Israel, meaning the leaders of Israel (Nolland 1993b:953). In the original context, the stone rejected by the builders refers to a nation rejected by the nations, meaning Israel and its king. Luke uses the same metaphor paradoxically: Jesus is rejected by his nation, Israel. 'The irony in the usage is that a psalm of national comfort now indicts them of unfaithfulness because of their opposition to God's commissioned one' (Bock 1996:1603).

The parable itself does not indicate Jesus' resurrection; it only promises judgement on his opponents. The cornerstone metaphor, however, must point to the vindication of Jesus by means of resurrection (cf. Ac 2:29-36). Perhaps Luke regarded the resurrection vindication of Jesus as preceding the appearance of the new Christian leadership of the early church (cf. Ac 1-2). By doing so, he was able to consider the Psalm 118 (117 LXX) citation as supporting the conclusion of the parable in which the vineyard falls into the hands of others.

(Nolland 1993b:953)

\section{The interpretation of Psalm 118 by Acts}

A comparison of the reading of the Greek texts of Ps 117:22 (LXX) with Ac 4:11 appears in Table 6.

TABLE 6

A comparison of the reading of the Greek texts of Psalm 117:22 (LXX) with Acts 4:11

\begin{tabular}{|c|c|}
\hline LXX & Ac 4:11 \\
\hline 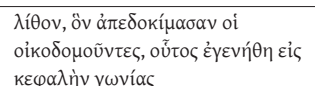 & 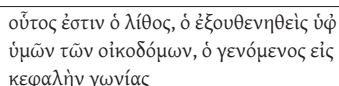 \\
\hline
\end{tabular}

Peter's defence and the prayer makes use of three different psalms: Psalm 118 (117 LXX):22 in Acts 4:11; Psalm 145:6 in Acts 4:24; and Psalm 2:1-2 in Acts 4:25b-26. Only Psalm 2 has an introductory formula (Doble 2004:97). Like Luke, Acts quoted only Psalm 118 (117 LXX):22, though there are some differences. Firstly, no introductory formula is given. Dunn (1996:53) sees the sentence as being close to a direct citation from Psalm 118 (117 LXX):22. Secondly, the wording is couched in the second

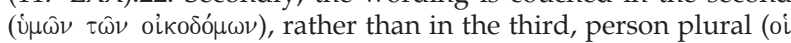

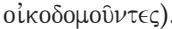

The middle clause has been made more forceful and turned into a petition of the charge of rejection (as in Ps 3:13-14) - not just rejected (passed over as unsuitable), but rejected with contempt (as in Lk 23:11 where the same verb is used), "by you the builders".

(Dunn 1996:53)
Thirdly, Luke substitutes the verb ' $\epsilon \xi o u \theta \in \nu \eta \theta \in i \varsigma^{\prime}$ ' (in the passive, to scorn) for the verb ' $\alpha \epsilon \in \delta o \kappa i ́ \mu \alpha \sigma \alpha v^{\prime}$ (in the active, to reject). The same verb is employed elsewhere to describe the attitude of the leaders (Lk 18:9) (Johnson 1992:78). Barrett appropriately states Luke's use of the term ' $k \xi \circ v \theta \in v \eta \dot{n} \theta \in\llcorner\nu$ ':

Wherever else in the NT there is an allusion to Ps 118:22 the LXX's word is used, and 'ं $\xi o v \theta \in v \eta^{\prime} \theta \in \omega \nu$ can hardly be called a Lucan word and adds the rewording of the Psalm is not Luke's own; it presumably came to him by tradition, and the tradition was in all probability a tradition of a speech, or at least was contained in a preaching context.

(Barrett 1994:230)

In order to account for such differences, Barrett's (1994:229) reasonable solution is that 'the sentence was adapted to the flow of Peter's argument'.

Wagner rightfully argues that Acts 4:11 functions to interpret Psalm 118 (117 LXX) in the Gospel of Luke:

At last Luke lays all his cards out on the table, as it were, making explicit the connections between PS 118 and the story of Jesus that up to now have been implied in the narrative rather than clearly stated. ... Ac 4:11 thus serves as the hermeneutical key to Luke's use of Ps 118 throughout the Gospel. For Luke, the psalm clearly prefigures the rejection and vindication of God's Messiah.

(Wagner 1997:173)

\section{CONCLUSION}

On the traditional-historical level, Luke understood the quotation from Psalm 118 in terms of tradition, where there is clear evidence of quotations from the psalm in the liturgical use of Psalm 118 in the scroll 11QPs a the Dead Sea Scrolls, as well as a Messianic-eschatological interpretation of Psalm 118 in the Dead Sea Scrolls and the Targum on Psalm 118.

On the hermeneutical level, regarding the function and interpretation of the quotation from Psalm 118 in Luke-Acts, the application of the New Exodus Motif is noteworthy. Psalm 118 (117 LXX):22 is cited twice in Luke-Acts (Lk 20:17; Ac 4:11). Acts 4:11 is the key to the interpretation of Psalm 118 (117 LXX):22 in Luke's Gospel. By means of such references, Luke describes Jesus as Isaiah's Suffering Servant, who is closely linked to the New Exodus. Psalm 118 (117 LXX):25-26 is also quoted twice in Luke (Lk 13:35; 19:38). Compared with Luke 13:35, the quotation of Psalm 118 (117 LXX):26 in Luke 19:38 adds 'ó $\beta \alpha \sigma\llcorner\lambda \in u \varsigma$ '. By means of the addition, Luke depicts Jesus as the Davidic king who leads the Isaianic New Exodus.

\section{REFERENCES}

Abegg, M., Flint P. \& Ulrich E. (eds.), 1999, The Dead Sea Scrolls Bible, Harper, San Francisco.

Barrett, C.K., 1994, The international critical commentary: Acts, T \& T Clark, Edinburgh.

Bock, D.L. 1996, Luke 9:51-24:53, in Exegetical commentary on the New Testament, vol. 3B, n.p., Baker, Grand Rapids.

Botha, P.J., 2003, Psalm 118 and social values in Ancient Israel, Old Testament Essays 16/2 (2003), 195-215.

Braude, W.G., 1959, Introduction to the Midrash on Psalms, in W.G. Braude (ed), The Midrash on Psalms, vol. 1, xi-xxxvi, Yale Judaica Series 13, Yale University Press, New Haven.

Brown, F., 1979, The new Brown-Driver-Briggs-Gesenius Hebrew and English lexicon, with an appendix containing the biblical Aramaic, Hedrickson, Massachusetts Peabody.

Brunson, A.C, 2003, Psalm 118 in the Gospel of John, Mohr Siebeck, Tübingen.

Dahood, M.S.J., 1970, Psalms 101-150: The Anchor Bible, vol. 17A, n.p., Doubleday, New York.

Daly-Denton, M., 2004, 'The Psalms in John's Gospel', in S. Moyise \& M.J.J. Menken (eds.), The Psalms in the New Testament, pp. 119-138, T\&T Clark, London. 
Denova, R.I., 1997, The things accomplished among us: Prophetic tradition in the structural pattern of Luke-Acts, Sheffield Academic Press, Sheffield.

De Vaux, R., 1980, Ancient Israel: Its life and institutions, Fietcher, London.

Doble, P., 2004, 'The Psalms in Luke-Acts', in S. Moyise \& M.J.J. Menken (eds.), The Psalms in the New Testament, pp. 83-117, T\&T Clark, London.

Dunn, J.D.G., 1988, 'Romans 9-16,' in Word biblical commentary, vol 38B, Word Books, Dallas.

Dunn, J.D.G., 1996, Epworth commentaries: The Acts of the Apostles, Epworth Press, London.

Dunn, J.D.G., 2000, Christ and the future in New Testament history, Brill, Leiden.

Ellis, E.E., 1966, The Gospel of Luke, Nelson, London.

Evans, C.A., 2001, 'Mark', in Word biblical commentary, vol. 34B, Thomas Nelson, Nashville.

Flint, P.W., 1997, 'The Dead Sea Psalms Scrolls and the Book of Psalms', Studies on the Texts of the Desert of Judah 17, Brill, Leiden.

Gärtner, B., 1953, 'א, ל a als Messiasbezeichnung', Svensk Exegetisk Årsbok XVIII-XIX, 98-108.

Goshen-Gottstein, M.H., 1966, The Psalm Scroll (11QPsa): A problem of canon and text, Textus 5, 22-33.

Hahn, S.W., 2005, Reading Luke: Interpretation, reflection, formation, Zondervan, Grand Rapids.

Jeremias, J., 1966, The Eucharistic words of Jesus, SCM, London.

Johnson, L.T., 1991, The Gospel of Luke, Liturgical Press, Collegeville.

Johnson, L.T., 1992, The Acts of the Apostles, Liturgical Press, Collegeville.

Kinman, B., 1995, Jesus' entry into Jerusalem: In the context of Lukan theology and the politics of his day, Brill, Leiden.

Kistemaker, S.J., 1961, The Psalm citations in the Epistle to the Hebrews, van Soest, Amsterdam.

Koet, B.J., 2005, 'Isaiah in Luke-Acts', in S. Moyise \& M.J.J. Menken (eds.), pp. 79-100, T\&T Clark, London.

Kraus, H.-J., 1986, Theology of the Psalms, trans. K. Crim, Augsburg, Minneapolis.

Kraus, H.-J., 1989, Psalms 60-150, trans. H.C. Oswald, Fortress Press, Minneapolis.

Leupold, H.C., 1972, Exposition of the Psalm, Evangelical Press, London.

Mays, J.L., 1988, 'Psalm 118 in the light of canonical analysis', in G.M. Tucker, D.L. Petersen, \& R.R. Wilson (eds.), Canon, theology, and Old Testament interpretation: Essays in honor of Brevand S Childs, pp. 299-311, Fortress, Philadelphia.

Menken, M.J.J., 2004, 'The Psalms in Matthew's Gospel', in S. Moyise \& M.J.J. Menken (eds.), The Psalms in the New Testament, pp. 61-82, T \& T Clark, London.

Moyise, S. \& Menken, M.J.J. (eds), 2004, The Psalms in the New Testament, T \& T Clark, London.

Nixon, R.E., 1963, The Exodus in the New Testament, Tyndale, London.
Nolland, J., 1993a, 'Luke 9:21-18:34', in Word biblical commentary, vol. 35B, n.p., Word Books, Dallas.

Nolland, J., 1993b, 'Luke 18:35-24:53', in Word biblical commentary, vol. 35C, n.p., Word Books, Dallas.

Pao, D.W., 2000, Acts and the Isaianic New Exodus, Wissenschaftliche Untersuchungen zum Neuen Testament 2, 130, Mohr Siebeck, Tübingen.

Prinsloo, G.T., 2003, A contextual and intertextual reading of Psalm 118, Old Testament Essays 16/2, 401-421.

Reiling, J., \& Swellengrebel, J.L., 1971, A translator's handbook on the Gospel of Luke, Brill, Leiden.

Ryken, L., Wilhoit, J. \& Longman, T. (eds), 1998, Dictionary of biblical imagery, pp. 251-255, IVP, Downers Grove.

Sanders, J.A., 1982, 'Isaiah in Luke', Interpretation 36, 144-155.

Schaefer, K., 2001, Psalms, Order of St Benedict, Minnesota.

Seccombe, D.P., 1981, 'Luke and Isaiah', New Testament Studies 27, 252-259.

Skehan, P.W., 1973, 'A liturgical complex in 11QPsa', Catholic Biblical Quarterly 34, 195-205.

Snodgrass, K., 1973, 'The Christological Stone Testimonia in the New Testament', PhD thesis, University of St. Andrews.

Snodgrass, K., 1983, 'The parable of the wicked tenants: An inquiry into parable interpretation', Wissenschaftliche Untersuchungen zum Neuen Testament 27.

Steyn, G.J., 2006, 'The occurrence of Psalm 118(117):6 in Hebrews 13:6: Possible liturgical origins?', Neotestamentica 40/1, 119_ 134.

Strack, H., \& Billerbeck, P., 1965, Kommentar zum Neuen Testament aus Talmud und Midrasch, vols. 1-6, 4th edn., C H Becksche Verlagsbuchhandlung, Munchen.

Strauss, M.L., 1995, 'The Davidic Messiah in Luke-Acts: The promise and its fulfilment in Lukan Christology', Journal for the Study of New Testament, suppl. 110, Sheffield, Sheffield Academic Press.

Swanson, S.R., 1992, 'Hallel', in D.N. Freedman (ed.), The Anchor Bible dictionary, vol. 3, Doubleday, New York.

Swete, H.B., 1900, An introduction to the Old Testament in Greek, Cambridge University Press, Cambridge.

Talmon, S., 1966, 'Pisqah be'emsa' pasuq and 11QPs ${ }^{a^{\prime}}$, Textus 5, 11-21.

Thomas, K.J., 1965, 'The Old Testament citations in Hebrews'. New Testament Studies 11, 303- 325.

Turner, M.M., 1996, Power from on high: The spirit in Israel's restoration and witness in Luke-Acts, Sheffield Academic Press, Sheffield.

Wacholder, B.Z., 1988, 'David's eschatological psalter: 11QPsalms ${ }^{\mathrm{a}^{\prime}}$. Hebrew Union College Annual 59, 23-72.

Wagner, J.R., 1997, 'Psalm 118 in Luke-Acts: Tracing a narrative thread', in C.A. Evans \& J.A. Sanders (eds.), Early Christian interpretation of the Scriptures of Israel: Investigations and proposals, 154-178, Sheffield Academic Press, Sheffield.

Werner, E., 1959, The sacred bridge, Dobson, London.

West, J.K., 1981, Introduction to the Old Testament, 2nd edn., Macmillan, New York. 